\title{
$\mathrm{SiC}$ 재료의 미세조직 및 열충격 특성 \\ 이상필* · 조경서** · 이현욱** · 손인수* • 이진경* \\ *동의대학교 기계공학과 \\ **동의대학교 일반대학원 기계공학과
}

\section{Microstructure and Thermal Shock Properties of SiC Materials}

\author{
Sang-Pill Lee*, Kyung-Seo Cho**, Hyun-Uk Lee**, In-Soo Son* and Jin-Kyung Lee* \\ *Department of Mechanical Engineering, Dong-Eui University, Busan, Korea \\ *Department of Mechanical Engineering, graduate school of Dong-Eui University, Busan, Korea
}

KEY WORDS: Flexural strength 굽힘강도, Liquid phase sintering 액상소결, Microstructure 미세구조, $\mathrm{SiC}$ 탄화규소, Thermal shock property 열충격 특성

\begin{abstract}
The thermal shock properties of SiC materials were investigated for high temperature applications. In particular, the effect of thermal shock temperature on the flexural strength of SiC materials was evaluated, in conjunction with a detailed analysis of their microstructures. The efficiency of a nondestructive technique using ultrasonic waves was also examined for the characterization of SiC materials suffering from a cyclic thermal shock history. SiC materials were fabricated by a liquid phase sintering process (LPS) associated with hot pressing, using a commercial submicron SiC powder. In the materials, a complex mixture of $\mathrm{Al}_{2} \mathrm{O}_{3}$ and $\mathrm{Y}_{2} \mathrm{O}_{3}$ powders was used as a sintering additive for the densification of the microstructure. Both the microstructure and mechanical properties of the sintered SiC materials were investigated using SEM, XRD, and a three point bending test. The SiC materials had a high density of about $3.12 \mathrm{Mg} / \mathrm{m3}$ and an excellent flexural strength of about $700 \mathrm{MPa}$, accompanying the creation of a secondary phase in the microstructure. The SiC materials exhibited a rapid propagation of cracks with an increase in the thermal shock temperature. The flexural strength of the SiC materials was greatly decreased at thermal shock temperatures higher than 70 $0^{\circ} \mathrm{C}$, due to the creation of microcracks and their propagation. In addition, the SiC materials had a clear tendency for a variation in the attenuation coefficient in ultrasonic waves with an increase in thermal shock cycles.
\end{abstract}

\section{1. 서 론}

최근 항공, 우주, 조선, 자동차 산업 및 원자력 산업 등의 발 전에 따라 고성능 철강재료와 더불어 세라믹스가 구조용 신소 재로 각광을 받고 있다. 특히, 차세대 선박의 고성능 엔진부품 및 핵융합로의 제 1벽, 블랑켓, 다이버터 및 냉각채널 등과 같 은 부품에 신소재의 활용이 기대되고 있다(Hasegawa et al, 2000; Jones et al, 2002). 이에 따라 우수한 특성의 재료를 개발 하여 제조기술의 확립을 통하여 산업용 구조재료로서 적용하고 자 노력하고 있다. 구조용 세라믹스에는 탄화규소( $\mathrm{SiC})$, 지르코 니아 $\left(\mathrm{ZrO}_{2}\right)$, 알루미나 $\left(\mathrm{Al}_{2} \mathrm{O}_{3}\right)$, 질화붕소 $(\mathrm{BN})$, 질화티탄 $(\mathrm{TiN})$ 등 이 있다. 일반적으로 $\mathrm{SiC}$ 재료는 CVI법(Chemical vapor infiltraion), PIP법(Polymer infiltration and pyrolysis), 반응소결법 (RS; Reaction sintering), 액상소결법(LPS; Liquid phase sintering)에 의해서 제조되고 있다(Dong et al., 2003; Lee et al., 2002). 그러나 CVI법과 PIP법의 경우에는 높은 밀도의 재료를 제조하기 어렵고 장시간의 생산주기에 따른 높은 비용과 두꺼 운 프리폼 $(>4 \mathrm{~mm})$ 은 강화섬유 직조물의 적층 공간에 기지재의 성형이 어려운 단점이 있다(Kotani et al., 2001; Katoh et al.,
2007). 또한 RS법의 경우는 미세조직에 형성되는 많은 잔류 실 리콘(Si)의 존재로 인해 기계적 특성이 낮아지는 경향을 보이고 있다(Lee et al., 2004). 이에 비해 액상 소결공정(LPS)은 산화물 소결조제를 이용하는 방법으로서 제조온도가 낮고 고상소결에 의해 제조된 탄화규소에 비해 $\mathrm{SiC}$ 입자 사이에 액상의 형성 및 확산을 통하여 높은 밀도를 제공함으로써 우수한 기계적 특성 을 보유하는 것으로 보고됨에 따라 액상소결에 대한 관심은 더 욱 증가되고 있다(Lee et al., 2009; Lee et al., 2006; 윤한기와 정 헌채, 2006). LPS-SiC 재료들의 기계적 특성은 다양한 소결재료 를 첨가하여 미세구조 강화를 통한 치밀화에 의해 개선되어 왔 다(Lee et al., 2010). $\mathrm{SiC}$ 재료의 특성은 초기분말의 입자크기에 크게 의존한다. 일반적으로 $\mathrm{SiC}$ 제조공정에서 초기 분말의 입경 감소는 입계에서 전위밀도를 증가시켜 강도 및 경도 특성의 향 상을 유도할 수 있으며 소결과정에서 미세조직의 치밀화를 유 발하는데 매우 효과적이다(이상필 등, 2008). 또한 이러한 $\mathrm{SiC}$ 재료는 뛰어난 고온강도, 내열성, 내마모성, 열적, 화학적 안정 성, 낮은 열팽창율 등의 뛰어난 특성으로 구조부재, 기계부재로 서 고온 환경 중에서 사용이 기대되는 재료이다(Katoh et al, 2007). $1000^{\circ} \mathrm{C}$ 이상의 극한 고온 환경이 되면 금속재료의 사용

교신저자 이상필: 부산광역시 부산진구 엄광로 995 051-890-1662 splee87@deu.ac.kr 
은 극도로 제한된다. 따라서 고온에서도 우수한 특성을 지니는 $\mathrm{SiC}$ 재료와 같은 세라믹스에 대한 연구가 활발히 진행되고 있 다. 그러나 $\mathrm{SiC}$ 재료는 우수한 제반특성에도 불구하고 취성이라 는 결정적인 약점이 아직까지 해결되고 있지 않은 실정이다. 또 한 우수한 고온 특성에도 불구하고 열충격에 의해서 발생한 세 라믹의 열팽창은 사용 중 심각한 파괴를 야기할 수 있다. 즉, 열 충격으로 발생한 열응력이 세라믹스 재료에 발생하였을 때 재 료표면의 균열을 동반하며 파괴로 이어진다. 상온에서 뿐만 아 니라 고온에서까지도 파괴에 상당히 영향을 미칠 때에 정상, 비 정상의 각종 조건하에서 발생하는 열응력이 중요한 파괴원인이 되고 있다. 또한 이방성으로 인한 잔류응력은 사용 환경에서 심 각한 응력변화를 일으킬 수 있다. 이러한 열응력은 상당히 커서 부품에 손상을 주거나 파괴시킬 수 있다(Hasselman and Singh, 1984). 따라서 세라믹스의 뛰어난 특성을 충분히 활용해가면서 구조용 부재로서 사용하기 위해서는 열충격에 대한 저항성의 평가가 매우 중요하다.

본 연구에서는 초미립 $\mathrm{SiC}$ 입자를 사용하여 액상소결공정으 로 제조한 $\mathrm{SiC}$ 재료의 소결특성을 평가하였다. 특히, 열충격 온 도의 증가에 따른 $\mathrm{SiC}$ 재료의 미세조직을 분석하고 강도 변화 를 조사하였다. 또한 초음파탐상기법을 사용하여 반복 열충격 시험을 실시한 $\mathrm{SiC}$ 재료에 대한 열충격과 감쇠계수와의 관계를 조사하였다.

\section{2. 실험방법}

\section{1 시험편 제조}

$\mathrm{SiC}$ 는 강한 공유결합을 형성하고 있기 때문에 소결조제 없이 상압소결 만으로는 고밀도 소결체를 얻기가 매우 어렵다. 이에 따라 본 연구에서 $\mathrm{SiC}$ 재료는 평균 입경이 $0.3 \mu \mathrm{m}$ 인 $\mathrm{SiC}$ 분말 (ß-type Ibiden Corp., Japan)을 사용하여 액상가압소결법으로 재료를 성형하였다. 액상소결법에 사용된 소결 첨가제는 $\mathrm{Al}_{2} \mathrm{O}_{3}$ 와 $\mathrm{Y}_{2} \mathrm{O}_{3}$ 분말(High Purity Chemical Corp., Japan)을 사용하였 으며 각각의 평균 입경은 $1 \mu \mathrm{m}$ 과 $2 \mu \mathrm{m}$ 이다. $\mathrm{Al}_{2} \mathrm{O}_{3}$ 와 $\mathrm{Y}_{2} \mathrm{O}_{3}$ 입자 의 첨가는 $\mathrm{SiC}$ 재료의 제조시 낮은 온도에서 높은 밀도와 고강 도를 확보하는데 유리하다. $\mathrm{SiC}$ 재료의 성형을 위해 $\mathrm{SiC}, \mathrm{Al}_{2} \mathrm{O}_{3}$, $\mathrm{Y}_{2} \mathrm{O}_{3}$ 와 아세톤의 복합 혼합물을 볼 밀링(Ball milling)을 사용하 여 복합 슬러리를 제조하였다. 혼합물의 제조를 위하여 배합속 도와 유지시간은 각각 $160 \mathrm{rpm}$ 과 12 시간으로 하였다. 그 후 건 조된 혼합슬러리를 사각형상의 판형 구조물에 넣고 고온프레스 (Hot press)를 이용하여 $1820^{\circ} \mathrm{C}$ 의 진공분위기에서 소결하였다. 또한 소결조제인 $\mathrm{Al}_{2} \mathrm{O}_{3}$ 와 $\mathrm{Y}_{2} \mathrm{O}_{3}$ 입자의 총 함량 $\left(\mathrm{Al}_{2} \mathrm{O}_{3}+\mathrm{Y}_{2} \mathrm{O}_{3}\right)$ 은 $10 \mathrm{wt} \%$ 로 일정하게 하였으며 소결조제의 혼합비 $\left(\mathrm{Al}_{2} \mathrm{O}_{3} / \mathrm{Y}_{2} \mathrm{O}_{3}\right)$ 는 1.5 로 고정하였다. 1.5 의 조성비의 경우에는 $1820^{\circ} \mathrm{C}$ 의 온도에서 소결조제가 액상으로 변화하여 치밀한 소결체를 얻을 수 있다 (Lee et al., 2006) 소결체의 제조를 위하여 가압력과 유지시간은 각각 $20 \mathrm{MPa}, 1$ 시간으로 하였다. 제조한 액상소결 $\mathrm{SiC}$ 재료는 사각형상의 판형 구조물로서 크기가 각각 $3(t) \times 40 \times 40 \mathrm{~mm}^{3}$ 과 $10(t) \times 40 \times 40 \mathrm{~mm}^{3}$ 이다.

\section{2 특성평가}

액상소결 $\mathrm{SiC}$ 재료의 소결밀도는 아르키메데스 원리를 이용 하여 측정하였으며 미세구조는 광학현미경과 주사형 전자현미 경(SEM)을 사용하여 관찰하였다. 특히, 열충격 온도에 따른 액 상소결 $\mathrm{SiC}$ 재료의 균열 거동을 관찰하였으며 X선 회절분석법 (XRD)을 사용하여 열충격 후 액상소결 $\mathrm{SiC}$ 재료의 미세조직에 생성되는 반응 생성물을 조사하였다.

액상소결 $\mathrm{SiC}$ 재료의 고온특성을 평가하기 위하여 반복 열충 격 시험을 수행하였다. Fig. 1은 반복 열충격 시험의 개략도를 나타낸다. 열충격 시험편은 약 $3 \mu \mathrm{m}$ 의 다이아몬드 입경을 가지 는 연마판을 사용하여 표면을 정밀하게 연마하였다. 열충격 온 도에 따른 액상소결 $\mathrm{SiC}$ 재료의 균열발생 및 성장거동을 조사 하기 위하여 연마된 시험편을 전기로 속에 넣고 시험온도까지 가열하여 30 분간 유지한 후 냉각수 속에 투하시켜 5분간 냉각 하였다. 열충격에 의한 액상소결 $\mathrm{SiC}$ 재료의 임계 굽힘강도를 평가하기 위하여 시험온도 차이의 범위는 $250^{\circ} \mathrm{C}$ 에서 $1100^{\circ} \mathrm{C}$ 로 하였다. 액상소결 $\mathrm{SiC}$ 재료의 강도는 열충격 후 3점 굽힘시험을 사용하여 상온에서 조사하였다. 액상소결 $\mathrm{SiC}$ 재료의 강도 평가 에 사용된 시험편의 크기는 $3(t) \times 4(w) \times 25(l) \mathrm{mm}^{2}$ 로 하였다. 굽힘 시험에 사용된 스팬(Span) 길이와 크로스헤드의 속도(Crosshead speed)는 각각 $18 \mathrm{~mm}$ 와 $0.5 \mathrm{~mm} / \mathrm{min}$ 로 하였다.

초음파를 이용한 비파괴 검사를 액상소결 $\mathrm{SiC}$ 재료의 특성을 조사하는데 사용하였다. 고체를 통해 전파되는 초음파 감쇠계 수는 음파의 임피던스와 초음파 에너지의 변화로부터 얻어지는 결과로서 재료의 치밀화 및 결함 검출을 평가하는데 유효하다. 초음파의 감쇠계수 변화는 파형의 진폭(Amplitude)감소를 이용

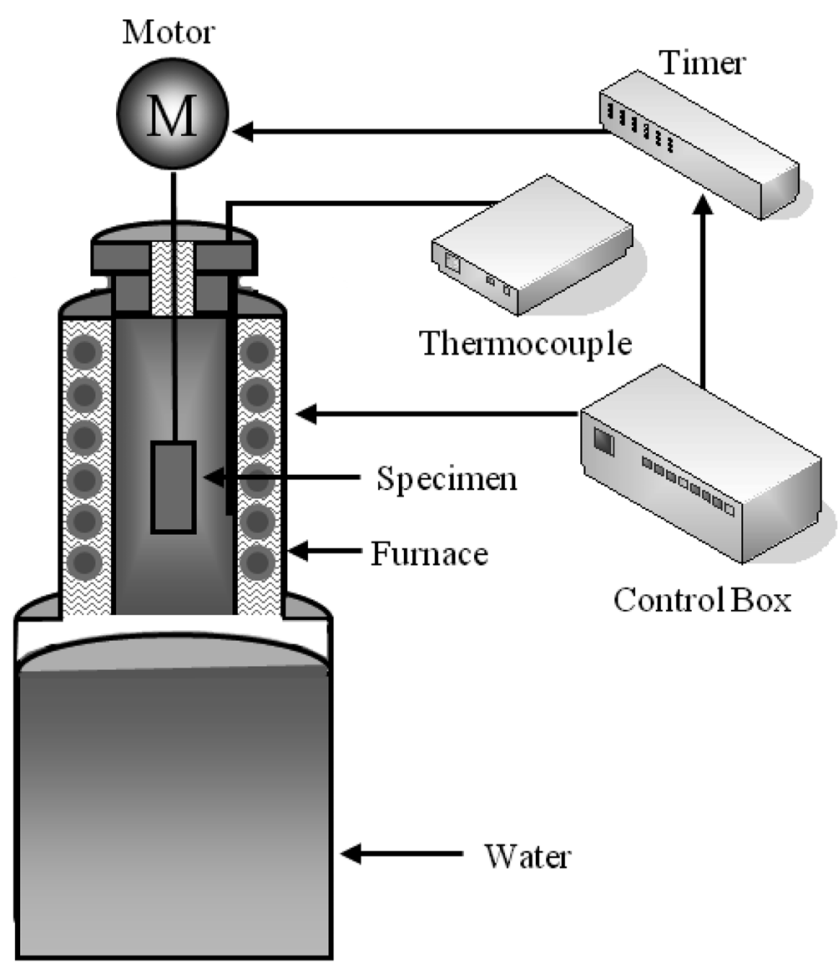

Fig. 1 Schematic diagram of cyclic thermal shock fatigue test 
하여 측정하였다. 특히, 열충격 온도의 증가에 따른 액상소결 $\mathrm{SiC}$ 재료의 감쇠특성을 평가하여 액상소결 $\mathrm{SiC}$ 재료의 손상 거 동을 조사하였다. 열충격에 따른 액상소결 $\mathrm{SiC}$ 재료의 초음파 특성은 수침법에 의해 측정되며 비파괴 시험 시스템은 초음파 의 정확한 측정과 분석을 위해 Pulse/receiver 장치, Oscilloscope와 컴퓨터로 구성되어 있다. 송신 탐촉자의 주파수 영역은 $10 \mathrm{MHz}$ 로 하였으며 시험편의 치수는 $10(t) \times 12(w) \times 12(l) \mathrm{mm}^{3}$ 로 하였다.

\section{3. 실험결과 및 고찰}

Fig. 2는 액상소결 $\mathrm{SiC}$ 재료의 제조에 사용된 $\mathrm{SiC}$ 초기 분말 에 대하여 $\mathrm{SEM}$ 을 사용하여 관찰한 결과를 나타낸다. $\mathrm{SiC}$ 상용 분말은 구형에 가깝고 평균 입경이 $0.3 \mu \mathrm{m}$ 로 알려져 있지만 다 소 불균일한 크기를 가지는 입자들이 관찰되었다. 다시 말하면 입자크기의 분포가 다소 균질하지 않다는 것을 알 수 있다. 이 러한 작은 입자와 큰 입자의 크기 분포가 큰 경우, 확산에 의한 입자합체 과정에서 작은 입자는 큰 입자로 합체하여 계속적인 성장을 하며 소결성에 영향을 미칠 수 있다. 또한 $\mathrm{SiC}$ 입자는 각진 형상을 나타내고 있으므로 이에 의해 소결과정에서 구형 의 입자들보다 입자간 접촉점 수가 적어지게 된다. 이러한 경 우, $\mathrm{SiC}$ 입자간 큰 기공의 존재와 비효율적인 확산을 초래하여 소결성을 저해할 수 있을 것으로 생각된다.

Fig. 3은 소결첨가제의 배합비 $\left(\mathrm{Al}_{2} \mathrm{O}_{3} / \mathrm{Y}_{2} \mathrm{O}_{3}\right)$ 를 1.5 로 하여 제조 한 액상소결 $\mathrm{SiC}$ 재료의 미세조직을 나타낸다. 소결온도는 182 $0{ }^{\circ} \mathrm{C}$ 로 일정하고 소결조제의 함량은 $10 \mathrm{wt} \%$ 로 하였다. 액상소결 $\mathrm{SiC}$ 재료는 소결과정에서 발생하는 미세균열과 같은소결 결점

이 없는 우수한 미세구조를 나타내었다. 액상소결SiC 재료의 미세조직은 회색영역의 $\mathrm{SiC}$ 상과 소결첨가제로 첨가한 $\mathrm{Al}_{2} \mathrm{O}_{3}$ 와 $\mathrm{Y}_{2} \mathrm{O}_{3}$ 입자의 화학반응에 의해 발생한 흰색영역의 2차상으로 구 성되어 있으며 일부 미세기공이 존재한다는 것을 알 수 있다.

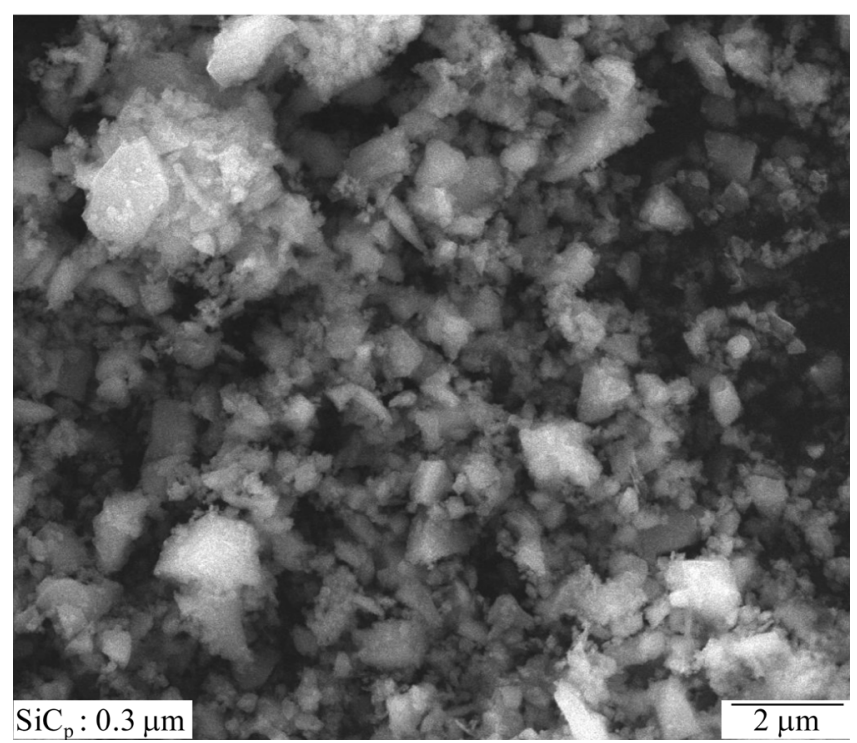

Fig. 2 Micrograph of commercial $\mathrm{SiC}$ powder

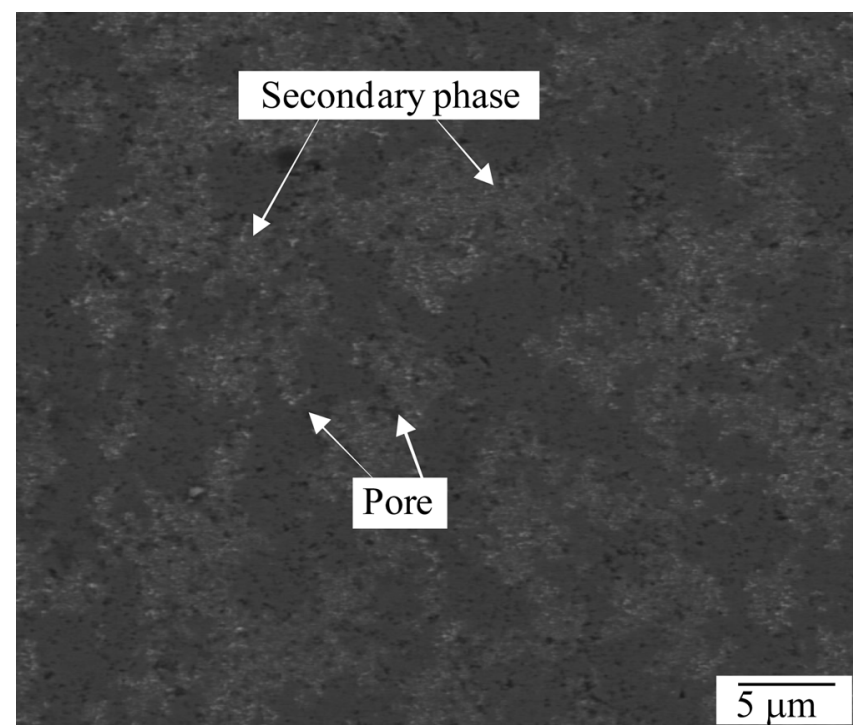

Fig. 3 Microstructure of sintered $\mathrm{SiC}$ materials.

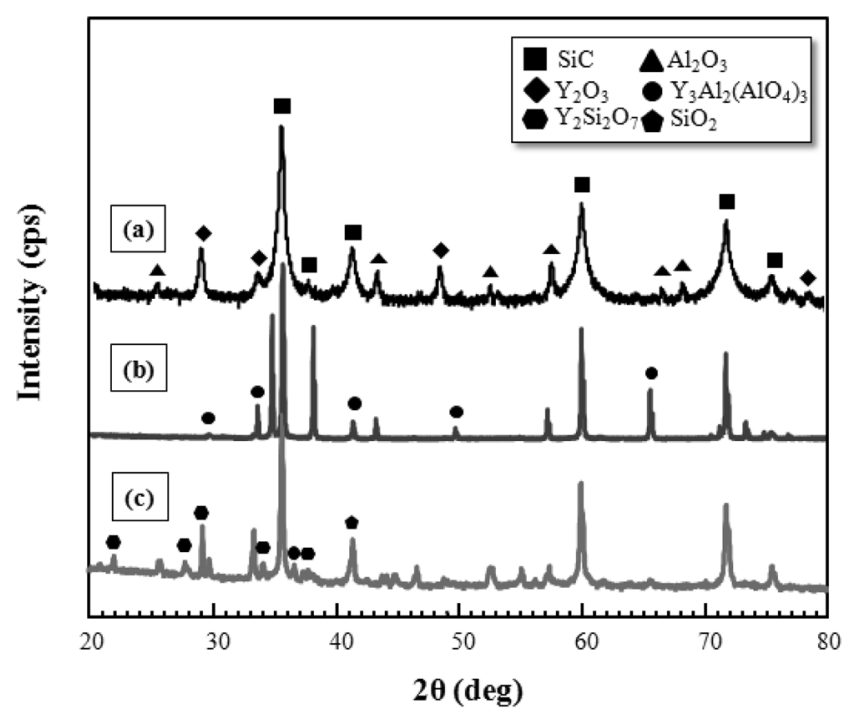

Fig. 4 XRD analysis results: (a) starting mixture powder, (b) sintered $\mathrm{SiC}$ materials and (c) thermal shocked $\mathrm{SiC}$ materials at the temperature difference of $900^{\circ} \mathrm{C}$

또한, 적절한 액상형성으로 미세조직 내에 2 차상의 형성이 균일 하고 액상의 기공 채움과 입자의 성장이 활발히 일어나면서 미 세기공이 그다지 발생하지 않는 것을 확인할 수 있다.

Fig. 4는 액상소결 $\mathrm{SiC}$ 재료의 미세조직에 대한 XRD 분석 결 과를 나타낸다. 또한 소결 전 혼합분말 $\left(\mathrm{SiC}+\mathrm{Al}_{2} \mathrm{O}_{3}+\mathrm{Y}_{2} \mathrm{O}_{3}\right)$ 과 열 충격을 부하한 $\mathrm{SiC}$ 재료에 대한 XRD 분석 결과를 나타내었다. 액상소결법으로 제조한 $\mathrm{SiC}$ 재료에서는 $\mathrm{SiC}, \mathrm{Al}_{2} \mathrm{O}_{3}, \mathrm{Y}_{2} \mathrm{O}_{3}$ 상이 검출되는 것을 알 수 있다. 특히, 미세조직에는 소결첨가제로 첨가한 $\mathrm{Al}_{2} \mathrm{O}_{3}$ 와 $\mathrm{Y}_{2} \mathrm{O}_{3}$ 입자의 화학적 반응에 의해 2차상으로서 YAG(Yttrium aluminum garnet)상으로 분류되는 $\mathrm{Y}_{3} \mathrm{Al}_{2}\left(\mathrm{AlO}_{4}\right)_{3}$ 상이 존재한다는 것을 분명히 알 수 있다. 이러한 2차상은 소결 과정에서 액상화된 첨가제가 무질서하게 형성되어 있는 기공을 채우면서 미세조직의 치밀화를 촉진하게 된다. 그러나 열팽창 
Table 1 Properties of monolithic SiC materials

\begin{tabular}{cc}
\hline \hline SiC particle size $[\mu \mathrm{m}]$ & 0.3 \\
\hline Sintering additives $\left[\mathrm{Al}_{2} \mathrm{O}_{3} / \mathrm{Y}_{2} \mathrm{O}_{3}\right]$ & 1.5 \\
\hline Sintered density $\left[\mathrm{Mg} / \mathrm{m}^{3}\right]$ & 3.12 \\
\hline Volume fraction of pore $[\%]$ & 5.5 \\
\hline Flexural strength $[\mathrm{MPa}]$ & 700 \\
\hline
\end{tabular}

계수가 다른 2차상이 다량으로 불균질하게 존재하게 되는 경우 는 내부 결함요인으로 작용하게 된다. 액상소결 $\mathrm{SiC}$ 재료의 입 경 크기 분포와 열충격에 의한 $\mathrm{SiC}$ 재료의 XRD 분석결과에 대 해서는 추후 기술한다.

Table 1은 액상소결 $\mathrm{SiC}$ 재료의 소결밀도과 굽힘강도를 나타 낸다. 액상소결 $\mathrm{SiC}$ 재료는 약 $3.12 \mathrm{Mg} / \mathrm{m}^{3}$ 의 우수한 소결밀도 를 나타내었다. 이러한 소결밀도는 이론밀도의 약 $95 \%$ 에 해당 하는 상대밀도를 의미한다. 또한 미세조직에 존재하는 기공율 은 약 $5.5 \%$ 를 나타내었다. 액상소결 $\mathrm{SiC}$ 재료의 굽힘강도는 5 개 의 시험편을 사용하여 얻어진 결과를 평균하여 산출하였다. 액 상소결 $\mathrm{SiC}$ 재료는 굽힘시험에서 전형적인 취성파괴 거동을 나 타내었다. 액상소결 $\mathrm{SiC}$ 재료는 높은 소결밀도로 인하여 약 $700 \mathrm{MPa}$ 에 해당하는 우수한 굽힘강도를 나타내었다.

Fig. 5는 굽힘시험을 실시한 액상소결 $\mathrm{SiC}$ 재료의 파단면을 관찰한 결과를 나타낸다. 액상소결 $\mathrm{SiC}$ 재료의 파단면에서는 다 소 균질하게 성장한 $\mathrm{SiC}$ 입자들을 확인할 수 있다. 또한 파단면 에는 $\mathrm{SiC}$ 입자의 주위에 미세기공이 존재한다는 것을 알 수 있 다. 액상소결 $\mathrm{SiC}$ 재료의 제조를 위하여 사용한 초기 $\mathrm{SiC}$ 입자 크기는 평균 약 $0.3 \mu \mathrm{m}$ 이었던 반면 소결 후의 $\mathrm{SiC}$ 입경은 초기 입자의 합체와 성장과정을 걸쳐 주로 약 $0.4 \sim 0.5 \mu \mathrm{m}$ 크기를 나 타내었으며 미세조직에 약 $64 \%$ 를 점유하고 있다.

Fig. 6는 열충격 온도차 변화에 따른 액상소결 $\mathrm{SiC}$ 재료의 열 충격 강도를 나타낸다. 열충격 강도 측정을 위한 굽힘시험은 각 열충격 온도에서 1 회의 열충격을 부하한 후 실시하였다. 열충격 을 부하하지 않은 액상소결 $\mathrm{SiC}$ 재료의 굽힘강도는 약 $700 \mathrm{MPa}$ 을 나타내었다. 액상소결 $\mathrm{SiC}$ 재료는 열충격 온도차가 증가함에 따라 약 $700^{\circ} \mathrm{C}$ 의 온도차까지 상온 굽힘강도를 일정하게 유지한 후 약 $800^{\circ} \mathrm{C}$ 의 열충격 온도차에서 급격한 강도 감소를 나타내 었다. 이것은 액상소결 $\mathrm{SiC}$ 재료에 있어서 임계 열충격 온도차가 약 $750^{\circ} \mathrm{C}$ 임을 실험적으로 나타낸다. 임계 열충격 온도차는 초기 시험편의 강도를 $100 \%$ 로 하였을 때 $50 \%$ 되는 지점에서 급격히 하강하는 강도곡선과 맞닿는 부분으로 정의된다. 또한 $800^{\circ} \mathrm{C}$ 이 상의 열충격 온도차에서 열이력을 받은 다수의 시험편들은 퀜 칭(Quenching) 직후 많은 미세균열이 발생하여 파단되는 경향 나타내었다.

Fig. 7은 열충격 온도차 변화에 따른 액상소결 $\mathrm{SiC}$ 재료의 표 면을 관찰한 결과를 나타낸다. 열충격 온도차가 증가할수록 균 열의 발생빈도가 높아지고 균열의 길이 또한 커짐을 알 수 있 다. 또한 열충격 온도차가 증가함에 따라 액상소결 $\mathrm{SiC}$ 재료의
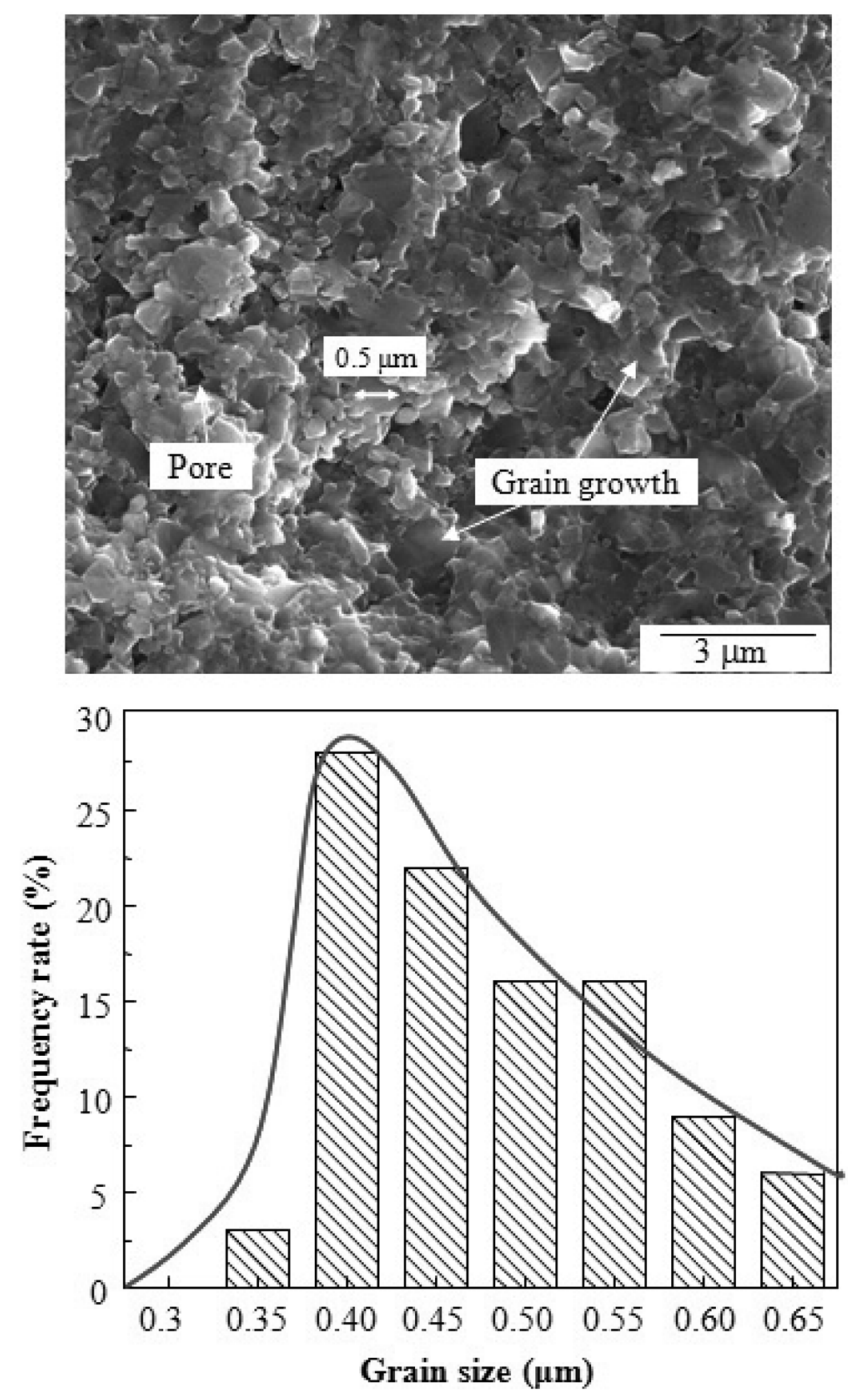

Fig. 5 Fracture surface and grain size of $\mathrm{SiC}$ materials

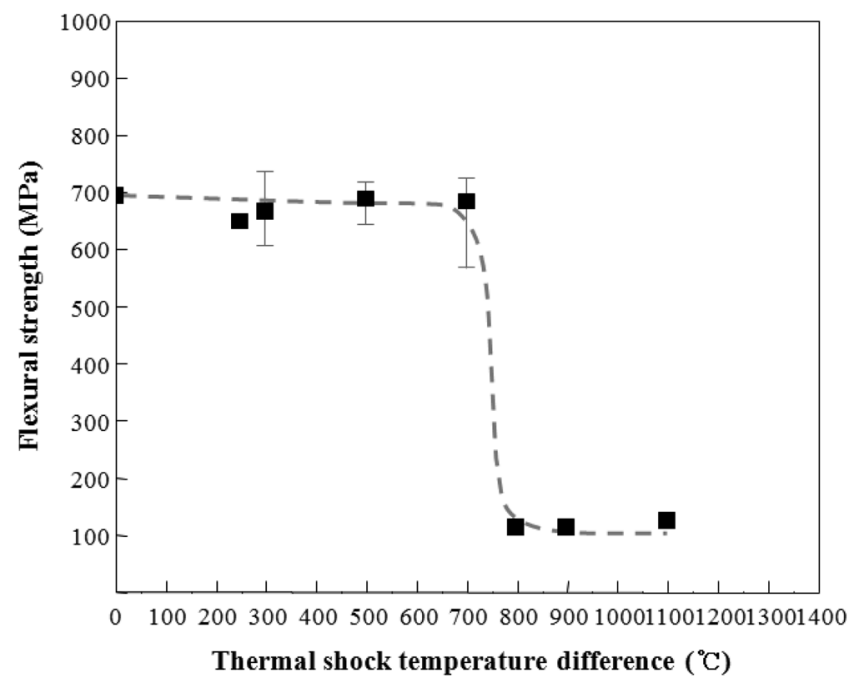

Fig. 6 Effect of thermal shock temperature difference on the flexural strength of $\mathrm{SiC}$ materials 

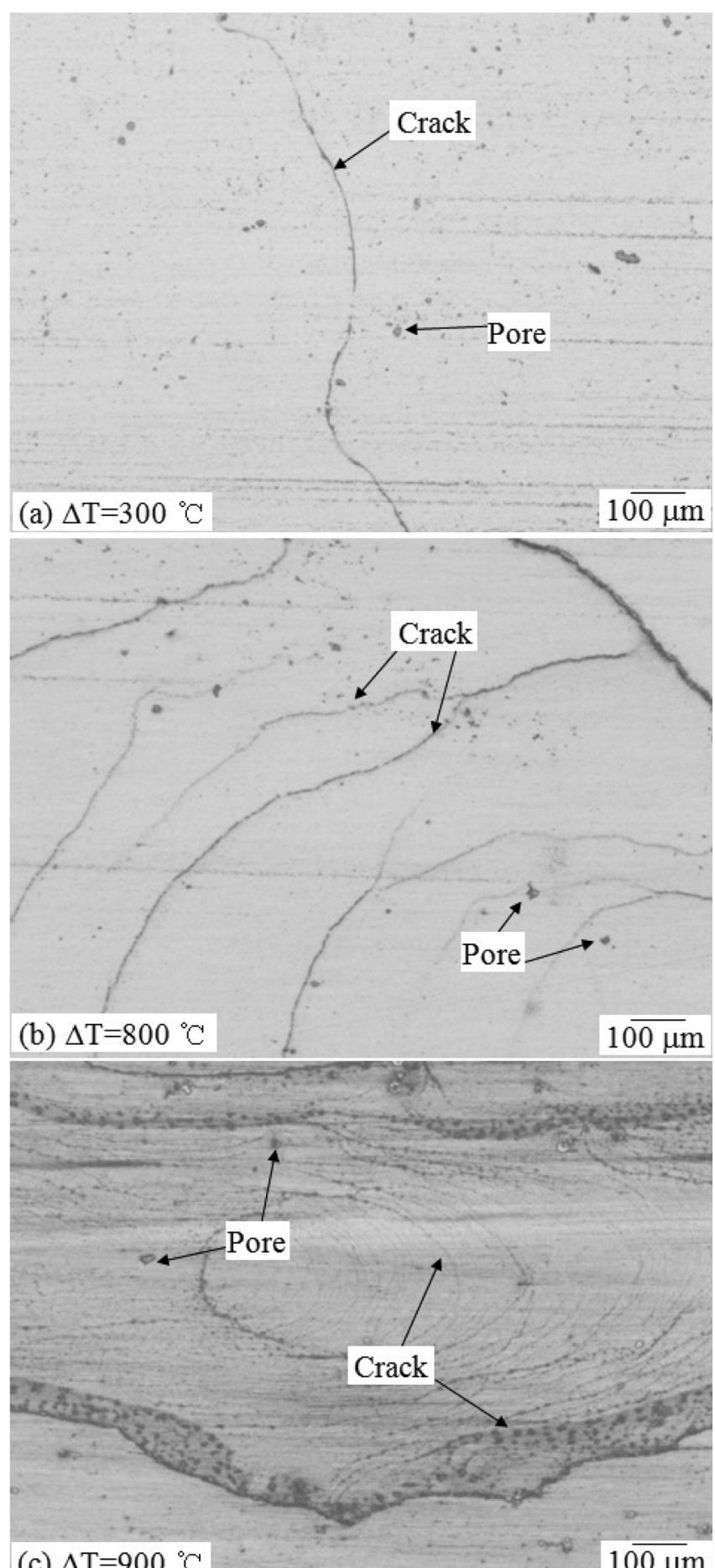

(c) $\Delta \mathrm{T}=900{ }^{\circ} \mathrm{C}$ $100 \mu \mathrm{m}$

Fig. 7 Microstructure of $\mathrm{SiC}$ materials suffered from different thermal shock temperatures

미세조직에는 시험온도까지의 열이력 노출 때문에 미세한 많은 기공이 발생하고 있다는 것을 할 수 있다. 이러한 급격한 균열 의 진전과 기공의 증가에 의하여 액상소결 $\mathrm{SiC}$ 재료의 강도가 열충격 온도차의 증가와 함께 저하한 것으로 생각된다. 또한 $900^{\circ} \mathrm{C}$ 이상의 고온에서 열충격을 받은 액상소결 $\mathrm{SiC}$ 재료의 표 면에는 얇은 피막을 형성하였다. 이러한 피막의 성질을 확인하
기 위하여 $\mathrm{XRD}$ 를 사용하여 분석한 결과를 열충격을 부하하지 않은 $\mathrm{SiC}$ 재료와 비교하기 위해 Fig. 4에 나타내었다. XRD의 성분분석 결과에 따르면 열충격을 받은 액상소결 $\mathrm{SiC}$ 재료의 미세조직에는 열충격을 받지 않은 액상소결 $\mathrm{SiC}$ 재료와는 달리 열이력에 의해 새로운 2차상으로서 $\mathrm{Y}_{2} \mathrm{Si}_{2} \mathrm{O}_{7}$ 과 $\mathrm{SiO}_{2}$ 가 형성되는 것을 알 수 있다. 특히 $\mathrm{SiO}_{2}$ 상은 고온으로 가열한 열처리로 내 에서 $\mathrm{SiC}$ 재료와 로 내에 존재하는 산소 $\left(\mathrm{O}_{2}\right)$ 가 반응하여 생성되 어 액상소결 $\mathrm{SiC}$ 재료의 표면에서 산화막으로 존재하는 것으로 생각된다.

Fig. 8은 열충격 횟수의 변화에 따른 액상소결 $\mathrm{SiC}$ 재료의 초 음파 감쇠계수를 나타내고 있다. 액상소결 $\mathrm{SiC}$ 재료에 대한 열 충격 온도차는 $250^{\circ} \mathrm{C}$ 로 하였다. 설정한 열충격 온도차는 액상소 결 $\mathrm{SiC}$ 재료가 1회 열충격에 의해 표면에 최초로 미소균열이 발생한 온도로 설정하였으며 열충격을 반복적으로 부하하여 재 료에 미치는 초음파 감쇠특성을 조사하였다. 3회까지의 열충격 을 부하하였을 때 초음파의 감쇠는 계속적으로 증가하는 경향 을 나타내었다. 또한 3회의 열충격에서 액상소결 $\mathrm{SiC}$ 재료는 다 수의 균열을 동반하면서 감쇠계수가 급격히 증가하였다. 특히, 3 회의 열충격을 부하한 경우에 액상소결 $\mathrm{SiC}$ 재료의 감쇠계수 는 약 $120 \mathrm{~dB} / \mathrm{m}$ 을 나타내었다. 이러한 감쇠계수는 열충격을 부 하하지 않은 액상소결 $\mathrm{SiC}$ 재료의 감쇠계수의 2 배에 상응하는 높은 수치를 나타내었다. 이와 같이 초음파를 이용한 비파괴기 법은 기계적 특성이 균열의 생성 및 성장에 크게 영향을 받는 세라믹스와 같은 소결재료의 특성 평가에 이용할 수 있을 것으 로 생각된다. 특히 초음파의 감쇠계수는 소결재료의 결함정도 를 파악하고 재료의 열화현상을 예측하는데 이용할 수 있을 것 으로 생각된다. 그러나 반복 열충격에 의한 재료의 열화 정도를 정확히 규정하기 위해서는 재료의 강도와 초음파 감쇠 계수와 의 상관관계를 조사하는 것이 필요하다.

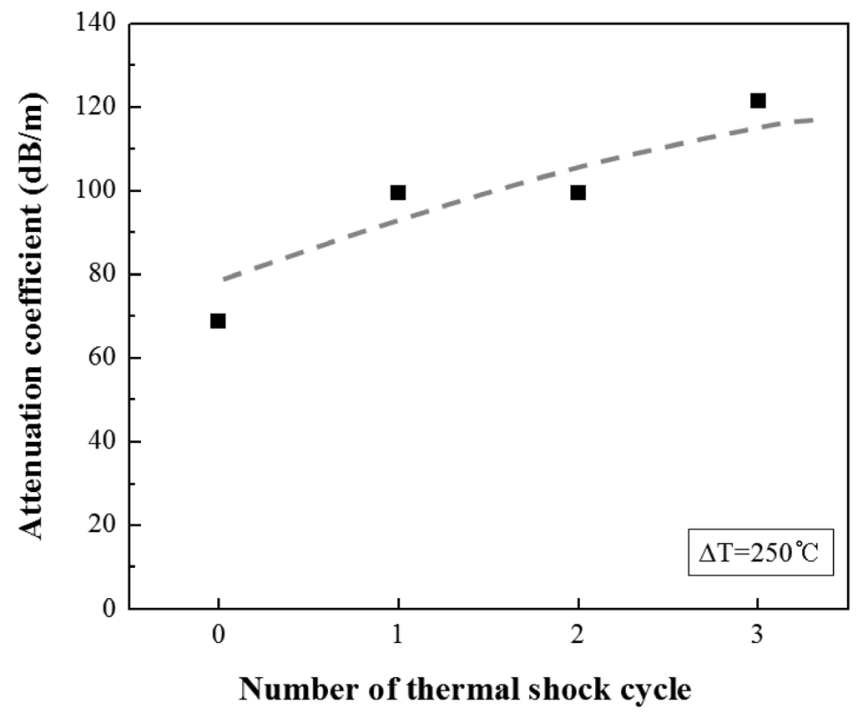

Fig. 8 Relationship between attenuation coefficient and thermal shock cycle in $\mathrm{SiC}$ materials 


\section{4. 결 론}

본 연구에서는 초미립 $\mathrm{SiC}$ 입자를 사용하여 액상소결공정으로 $\mathrm{SiC}$ 재료를 제조하고 미세조직과 열충격 특성을 조사하였다. 또한 액상소결 $\mathrm{SiC}$ 재료에 반복적으로 열충격을 부하하여 열충격에 따른 초음파의 감쇠계수 변화를 조사하여 다음과 같은 결론을 얻었다.

(1) 액상소결 $\mathrm{SiC}$ 재료는 이론밀도의 약 $95 \%$ 에 해당하는 $3.12 \mathrm{Mg} / \mathrm{m}^{3}$ 의 우수한 소결밀도를 나타내었다. 또한 미세 기공이 관찰되지만 소결첨가제의 반응에 의해 2차상을 형성하면서 치 밀한 미세조직을 나타내었다.

(2) 액상소결 $\mathrm{SiC}$ 재료는 상온에서 약 $700 \mathrm{MPa}$ 의 굽힘강도를 나타내었다. 이러한 상온강도는 열충격 온도차의 상승과 함께 균열의 발생과 성장이 증가하여 $700^{\circ} \mathrm{C}$ 이상의 열충격 온도차에서 급격히 감소하였다.

(3) $900^{\circ} \mathrm{C}$ 의 온도차에서 열충격을 받은 액상소결 $\mathrm{SiC}$ 재료의 표면에는 $\mathrm{SiC}$ 재료와 열처리로 내에 존재하는 산소 $\left(\mathrm{O}_{2}\right)$ 가 반응 하여 $\mathrm{SiO} 2$ 로 구성된 산화막을 형성하였다. 또한 미세조직에는 새로운 2차상으로서 $\mathrm{Y}_{2} \mathrm{Si}_{2} \mathrm{O}_{7}$ 상이 형성되었다.

(4) 액상소결 $\mathrm{SiC}$ 재료는 열충격 반복횟수가 증가할수록 초음 파의 감쇠계수가 증가하였다. 특히, $250^{\circ} \mathrm{C}$ 의 온도차에서 열충격 을 3회 부하한 액상소결 $\mathrm{SiC}$ 재료의 감쇠계수는 열충격을 받지 않은 재료의 약 2 배에 상응하는 높은 수치를 나타내었다.

\section{후 기}

본 논문은 2009학년도 동의대학교 연구년 지원에 의하여 연구되었습니다.

\section{참 고 문 헌}

윤한기, 정헌채 (2006). “LPS-SiC 세라믹스의 굽힘강도 특성에 미치는 미시조직 영향", 제20권, 제6호, 한국해양공학회지, pp 96-100.

이상필, 이문희, 이진경 (2008). " $\mathrm{Al}_{2} \mathrm{O}_{3}$ 와 $\mathrm{Y}_{2} \mathrm{O}_{3}$ 입자를 함유한 액상소결 $\mathrm{SiC}$ 재료의 특성”, 제 22 권, 제 4 호, 한국해양공학 회지, pp 59-63.

Dong, S., Katoh, Y., Kohyama, A. (2003). "Processing Optimization and Mechanical Evaluation of Hot Pressed 2D Tyranno-SA/SiC Composites", Journal of the European Ceramic Society, Vol 23, pp 1223-1231.

Hasegawa, A., Kohyama, A., Jones, R.H., Snead, L.L. and Fenici, P.(2000). "Critical Issue and Current Status of
$\mathrm{SiC} / \mathrm{SiC}$ Composite for Fusion", Journal of Nuclear Materials. Vol 283-287, pp 128-137.

Hasselman, D.P.H. and Singh, J.P. (1984). "Role of Mixed-Mode Crack Propagation in Thermally Shocked Bbrittle Materials", Theoretical and Applied Fracture Mechanics, Vol 2, pp 59-65.

Jones, R.H., Hasegawa, L.A., Katoh, Y., Kohyama, A., Riccardi, B., Snead, L.L., and Weber, W.J. (2002). "Promise and Challenges of $\mathrm{SiCf} / \mathrm{SiC}$ Composite for Fusion Energy Applications", Journal of Nuclear Materials. Vol 307-311, pp 1057-1072.

Katoh, Y., Snead, L.L., Henager, C.H. Jr., Hasegawa A., Kohyama A., Riccardi, B. and Hegeman H., (2007). "Current Status and Critical Issues for Development of $\mathrm{SiC}$ Composites for Fusion Applications", Journal of Nuclear Materials. Vol 367-370, pp 659-671.

Kotani, M., Kohyama, A. and Katoh, Y. (2001). "Development of $\mathrm{SiC} / \mathrm{SiC}$ Composites by PIP in Combination with RS", Journal of Nuclear Materials, Vol 289, pp 37-41.

Lee, S.P., Park, J.S., Katoh, Y., Kohyama, A., Kim, D.H., Lee, J.K. and Yoon, H.K. (2002). "Process, Microstructure and Flexural Properties of Reaction Sintered Tyranno SA/SiC composites", Journal of Nuclear Materials, Vol 307-311, pp 1191-1195.

Lee, S.P., Jin, J.O., Park, J.S. and Koyama, A. (2004). “High Temperature Characterization of Reaction Sintered SiC Based Materials", Journal of Nuclear Materials, Vol 329333, pp 534-538.

Lee, S.P., Shin, Y.S., Bae, D.S., Min, B.H., Park, J.S. and Koyama, A. (2006). "Fabrication of Liquid Phase Sintered $\mathrm{SiC}$ Materials and Their Characterization", Fusion Engineering and Design, Vol 81, pp 963-967.

Lee, J.K., Lee, S.P., Cho, K.S., Lee, J.H. and Kohyama, A. (2009). "Characterization Evaluation of Liquid PhaseSintered SiC Materials by a Nondestructive Technique", Journal of Nuclear Materials, Vol 386-388, pp 487-490.

Lee, J.K., Lee, S.P. and Byun, J.H. (2010). “Charaterization of $\mathrm{SiC}$ Based Composite Materials by the Infiltration of Ultra-Fine SiC Particles", Fusion Engineering and Design, Vol 85, pp 1376-1380.

2011년 4월 11일 원고 접수 2011년 6월 10일 심사 완료 2011년 6월 20일 게재 확정 